\title{
EVALUASI TINGKAT PENERIMAAN E-LEARNING PADA MAHASISWA BIDANG KEILMUAN SOSIAL DAN TEKNIK DENGAN TECHNOLOGY ACCEPTANCE MODEL (TAM)
}

\author{
EVALUATION OF E-LEARNING ACCEPTANCE LEVELS \\ IN STUDENTS IN THE SOCIAL AND TECHNIQUE SCIENCE \\ WITH TECHNOLOGY ACCEPTANCE MODEL (TAM)
}

Oleh:

Liana Dewi

Program Studi Magister Sains Akuntansi Universitas Jenderal Soedirman lianadewi73@gmail.com

Anisa Sains Kharisma

Program Studi Magister Sains Akuntansi Universitas Jenderal Soedirman anisasains08@gmail.com

Adib Noor Asy'ari

Program Studi Magister Sains Akuntansi Universitas Jenderal Soedirman anandz@myself.com

\begin{abstract}
Abstrak
Belum optimalnya penggunaan e-learning sebagai media pembelajaran di perguruan tinggi merupakan salah satu hal yang menarik untuk diteliti. Penelitian ini bertujuan untuk melakukan evaluasi terhadap tingkat penerimaan penggunaan e-learning sebagai media pembelajaran yang diterapkan di suatu institusi pendidikan dengan menggunakan pendekatan Technology Acceptance Model (TAM). Sample dalam penelitian ini berjumlah 60 orang mahasiswa jurusan Akuntansi dan Teknik Informatika yang pernah menggunakan e-learning dalam proses perkuliahan. Data dikumpulkan dengan cara kuisioner, terdiri dari 30 pertanyaan dan dianalisis menggunakan metode regresi. Hasil dari pengujian dengan regresi menunjukan bahwa mahasiswa jurusan Akuntansi dan Teknik Informatika memiliki motivasi yang baik dalam penggunaan e-learning sebagai media pembelajaran. Pada mahasiswa jurusan Akuntansi persepsi kegunaan, lebih mendominasi motivasi mahasiswa dalam penggunaan e-learning, sedangkan pada mahasiswa jurusan Teknik Informatika persepsi kemudahan mendominasi motivasi penggunaan e-learning.
\end{abstract}

Kata kunci: e-learning, mahasiswa, TAM

\begin{abstract}
Not yet optimal use of e-learning as a medium of learning in tertiary institutions is one of the interesting things to study. This study aims to evaluate the level of acceptance of the use of e-learning as a learning medium that is applied in an educational institution using the Technology Acceptance Model (TAM) approach. The sample in this study amounted to 60 students majoring in Accounting and Information Engineering who have used e-learning in the lecture process. Data were collected by questionnaire, consisting of 30 questions and analyzed using the regression method. The results of the regression test show that students majoring in Accounting and Information Engineering have good motivation in the use of e-learning as a
\end{abstract}


learning medium. In students majoring in Accounting perceptions of usefulness, more dominates student motivation in the use of e-learning, whereas for students majoring in Informatics Engineering perceptions of ease dominate motivation for using e-learning.

Keywords: e-learning, students, TAM.

\section{PENDAHULUAN}

Penerapan teknologi informasi dalam berbagai bidang kehidupan semakin meningkat, hal ini dilakukan untuk memberikan kemudahan dalam melakukan suatu pekerjaan. Penggunaan perangkat elektronik sebagai penunjang pembelajaran merupakan salah satu contoh implementasi teknologi informasi. Penerapan teknologi informasi dalam penyampaian materi oleh pendidik diharapkan dapat meningkatkan kualitas pembelajaran (Harahap, 2015). Electronic Learning (e-learning) merupakan salah satu contoh penerapan teknologi informasi dalam proses pembelajaran.

Penggunaan e-learning dalam proses pembelajaran di berbagai jenjang pendidikan khususnya pendidikan menengah dan pendidikan tinggi terus meningkat (Felix \& Wirawan, 2014). Penerapan e-learning telah mendorong perubahan konsep pembelajaran konvensional menjadi pembelajaran berbasis teknologi digital yang memungkinkan pembelajaran dilakukan dalam waktu dan tempat yang lebih fleksibel serta mengubah sistem pembelajaran yang sebelumnya bersifat Teacher Center Learning (TCL) menjadi Student Center Learning (SCL) (Yulianto, 2011).

Dibalik berbagai kemudahan yang ditawarkan $e$-learning, terdapat beberapa kendala yang menyebabkan penerapan e-learning dalam proses pembelajaran tidak berjalan secara optimal (Asrori \& Fachrurrozie, 2011), (Briosandhi, 2011). Kendala dalam penerapan sistem e-learning dapat berasal dari pendidik maupun peserta didik (Asrori \& Fachrurrozie, 2011), (Briosandhi, 2011). Menurut Davis dalam Simanjuntak (2011), TAM dapat digunakan untuk mempelajari persepsi penerimaan teknologi dalam dua aspek yaitu persepsi pengguna terhadap kemudahan penggunaan teknologi dan persepsi pengguna terhadap manfaat teknologi. Mahasiswa sebagai salah satu pengguna e-learning di suatu perguruan tinggi yang terdiri dari berbagai program studi, mempunyai tingkat pemahaman yang bervariasi terhadap penggunaan teknologi informasi.

Beberapa penelitian terkait pengukuran tingkat penerimaan penggunaan e-learning, telah dilakukan dalam penelitian sebelumnya, diantaranya: penelitian tentang perbedaan para Akuntan dan ICT programer terhadap penerimaan teknologi dalam melaksanakan pekerjaannya (Caldarelli, Ferri, Maffei, \& Spanò, 2019). Hasil penelitiannya menujukan bahwa ada pengaruh yang signifikan secara statistik dari variabel pribadi dalam beberapa aspek niat untuk menggunakan sistem informasi. Orang yang bekerja di bidang Teknologi Informasi dan Komunikasi (TIK) memiliki tingkat penerimaan yang lebih kuat terhadap teknologi baru daripada akuntan. Pembentukan pribadi dan gender juga merupakan variabel yang berperan penting dalam proses penerimaan TIK.

Penelitian lainnya, mencoba mengukur respon mahasiswa terhadap penggunaan teknologi informasi dalam proses pembelajaran di suatu institusi pendidikan, (El-Seoud, Taj-Eddin, Seddiek, El-Khouly, \& Nosseir, 2014). Hasil penelitiannya menunjukan bahwa tingkat penerimaan teknologi dipengaruhi oleh bidang keilmuan atau program studi yang dipilih.

Berdasarkan masalah tersebut, dalam penelitian ini akan dilakukan pengukuran tingkat penerimaan penggunaan e-learning pada mahasiswa dari bidang keilmuan berbeda. Program studi Teknik Informatika mewakili bidang ilmu teknik dan program studi Akuntansi mewakili bidang ilmu sosial dipilih dalam penelitian ini sebagai sampel dalam pengukuran tingkat penerimaan e-learning dengan menggunakan pendekatan TAM. 


\section{KERANGKA PEMIKIRAN TEORITIS DAN PENGEMBANGAN HIPOTESIS}

\section{Technology Acceptance Model (TAM)}

Berbagai penelitian mengenai penerapan teknologi informasi dengan menggunakan pendekatan TAM telah dilakukan sebalumnya. Davis dalam Asrori \& Fachrurozie (2011), mengemukakan bahwa minat penggunaan teknologi tergantung pada persepsi kegunaan (preceived of usefulness) dan persepsi kemudahan dalam penggunaan (preceived ease of use) seperti ditampilkan pada gambar 1.

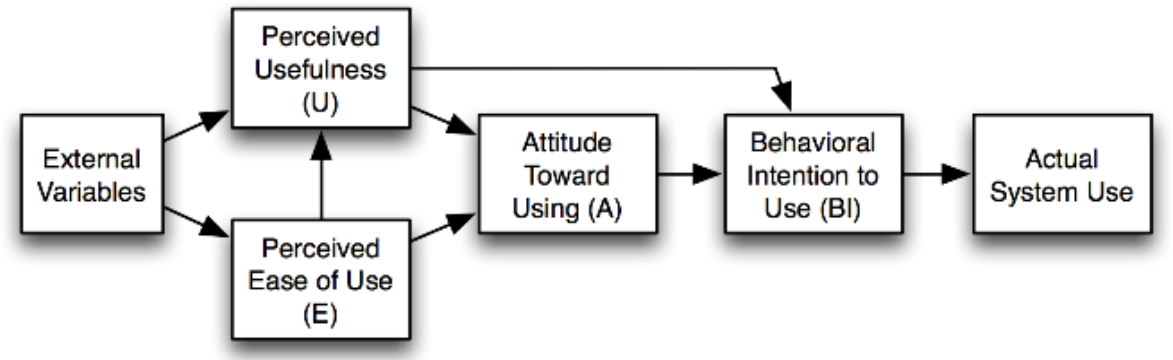

Gambar 1. Model TAM (Davis, Bagozzi , \& Warshaw , 1989)

\section{E-learning}

Metode pembelajaran dengan menggunakan teknologi informasi dan internet sangat membantu dalam meningkatkan efisiensi dan efektifitas penyampaian dan penyerapan materi pembelajaran. Bahkan dengan pemanfaatan teknologi ini dapat mempermudah pendidik dalam berkomunikasi dengan peserta didik. Yulianto (2011) menyatakan bahwa ada 3 elemen yang saling berkaitan dalam penerapan teknologi informasi diantaranya adalah perangkat keras (Hardware), perangkat lunak (Software) dan pengguna (Brainware). Ketiganya harus berfungsi dengan baik supaya dapat menghasilkan output optimal dari inputnya. Metode pembelajaran dengan penerapan teknologi dan internet tentunya berbeda dengan metode pembelajaran konvensional. Menurut Sokeartawi dalam Yulianto (2011) terdapat perbedaan antara pembelajaran konvensional dan pembelajaran berbasis internet seperti ditampilkan pada Tabel 1.

Tabel 1. Perbandingan pembelajaran konvensional dan pembelajaran berbasis internet

\begin{tabular}{|c|c|c|}
\hline No & Pembelajaran Konvensional & Pembelajaran Berbasis Internet \\
\hline 1. & $\begin{array}{l}\text { Ada pertemuan tatap muka antara pendidik } \\
\text { dengan peserta didik }\end{array}$ & $\begin{array}{l}\text { Tidak memerlukan adanya tatap } \\
\text { muka antara pendidik dengan peserta } \\
\text { didik }\end{array}$ \\
\hline 2. & Waktu pembelajaran sesuai jadwal & Waktu pembelajaran lebih fleksibel \\
\hline & Membutuhkan ruang kelas & Tidak membutuhkan ruang kelas \\
\hline & Terpusat pada pendidik & Terpusat pada peserta didik \\
\hline & Siswa cenderung pasif & Siswa aktif \\
\hline & Waktu pembelajaran terbatas & Tidak ada batasan waktu \\
\hline & Guru sebagai subjek & Siswa sebagai subjek \\
\hline & Pola belajar siswa tergantung guru & Siswa belajar secara mandiri \\
\hline & Materi pembelajaran dari guru & $\begin{array}{l}\text { Materi pembelajaran dapat diperoleh } \\
\text { sendiri }\end{array}$ \\
\hline
\end{tabular}


Metode pembelajaran dengan penerapan teknologi salah satunya yaitu e-learning. Menurut Yulianto (2011) e-learning adalah metode pembelajaran berbasis teknologi dan internet yang bertujuan untuk meningkatkan kualitas pembelajaran serta keberhasilannya bergantung pada sejauh mana penerapan dan pemanfaatan oleh pendidik dan peserta didik. Persyaratan pembelajaran berbasis e-learning diantaranya: tersedianya jaringan internet, tersedianya perangkat keras yang mendukung kegiatan pembelajaran, tersedianya tutor, adanya lembaga yang menyelenggarakan dan mengelola e-learning, rancangan sistem pembelajaran, sikap penerimaan positif dari peserta didik dan pendidik, adanya evaluasi terhadap penerapan $e$ learning untuk pembelajaran serta adanya feedback (Hartanto, 2016).

Menurut Romi Satria Wahono dalam Hartanto (2016), komponen e-learning terdiri dari infrastruktur e-learning yaitu perangkat keras komputer, sistem dan aplikasi $e$-learning yaitu perangkat lunak yang memvirtualisasi kegiatan pembelajaran, konten e-learning yaitu bahan ajar serta tutor sebagai pelaku utama pembelajaran. Keseluruhan komponen tersebut perlu diperhatikan karena saling mendukung satu sama lain dalam keberhasilan proses pembelajaran dengan e-learning.

Penggunaan e-learning dalam proses pembelajaran ini memberikan banyak manfaat diantaranya: memberikan keleluasaan waktu dan tempat, memberikan kesempatan bagi peserta didik untuk memegang kendali dalam proses pembelajaran, mengurangi biaya, kecepatan proses pembelajaran dapat disesuaikan dengan kemampuan masing-masing peserta didik, standarisasi pengajaran, efektifitas pengajaran, kecepatan distribusi, dapat diakses kapanpun dan otomatiasi proses e-learning (Hartanto, 2016). Dengan keunggulan utama dalam hal fleksibilitas tentunya $e$-learning dapat memungkinkan setiap peserta didik untuk meningkatkan motivasi belajarnya sehingga akan meningkatkan penyerapan materi pembelajaran dengan lebih baik.

Selain manfaat yang memungkinkan peserta didik untuk melakukan proses pembelajaran dengan lebih baik dan mudah, e-learning membutuhkan peran pendidik sebagai pelaku utama terselenggaranya proses pembelajaran. Kesuksesan e-learning tidak hanya bersumber dari kemampuan dan kemauan peserta didik dalam menggunakan aplikasi ini namun juga tergantung pada pendidik sebagai pengelola materi pembelajaran. Beberapa kompetensi perlu dimiliki pendidik dalam melakukan proses pembelajaran dengan e-learning ini diantaranya: kemampuan untuk membuat desain instruksional yang sesuai dengan rencana pembelajaran, kemampuan menggunakan teknologi dalam pembelajaran dan penguasaan materi pembelajaran sesuai dengan keahliannya (Hartanto, 2016).

\section{Penerapan Technology Acceptance Model (TAM) dalam E-Learning}

Penelitian mengenai implementasi $e$-learning menggunakan TAM sebagai teori dasar untuk menjelaskan berbagai fenomena dalam penerapan e-learning (Yulianto, 2011), (Asrori \& Fachrurrozie, 2011). Penelitian-penelitian sebelumnya mendukung adanya hubungan positif antara persepsi kegunaan dan persepsi kemudahan penggunaan teknologi dengan minat penggunaan teknologi (Asrori \& Fachrurrozie, 2011), (Sefrika, 2018), (Felix \& Wirawan, 2014), (Yulianto, 2011).

Penelitian ini selanjutnya mempelajari pengaruh perspektif kegunaan dan kemudahan terhadap minat penggunaan e-learning berdasarkan latar belakang akademis untuk melihat perbedaan persepsi penerimaan penggunaan e-learning pada mahasiswa dari dua bidang keilmuan yang berbeda. Berdasarkan penjelasan sebelumnya, secara umum model penelitian yang dilakukan ditampilkan pada gambar 2 . 


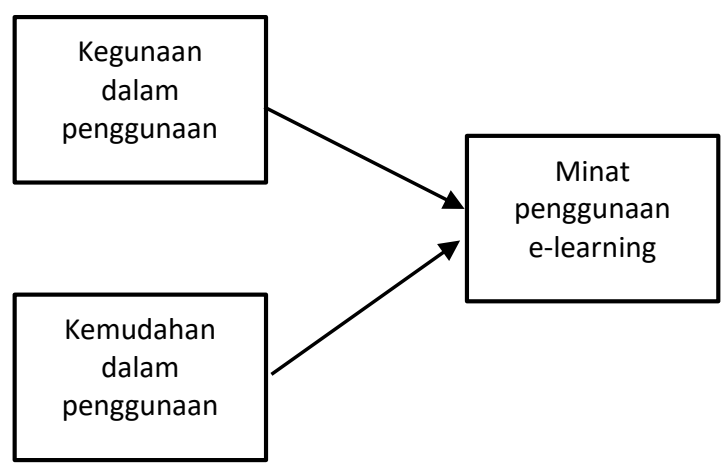

Gambar 2. Model Penelitian

Adapun rumusan hipotesis dalam penelitian ini adalah sebagai berikut:

H1a: Persepsi kegunaan dalam penggunaan berpengaruh positif terhadap minat penggunaan e-learning sebagai media pembelajaran pada Mahasiswa Akuntansi.

$\mathrm{H} 1 \mathrm{~b}$ : Persepsi kegunaan dalam penggunaan berpengaruh positif terhadap minat penggunaan e-learning sebagai media pembelajaran pada Mahasiswa Teknik Informatika.

$\mathrm{H} 2 \mathrm{a}$ : Persepsi kemudahan dalam penggunaan berpengaruh positif terhadap minat penggunaan e-learning sebagai media pembelajaran pada Mahasiswa Akuntansi.

$\mathrm{H} 2 \mathrm{~b}$ : Persepsi Kemudahan dalam penggunaan berpengaruh positif terhadap minat penggunaan e-learning sebagai media pembelajaran pada Mahasiswa Teknik Informatika.

\section{METODE PENELITIAN}

\section{Desain Penelitian}

Jenis penelitian yang dilakukan adalah penelitian kuantitatif, yaitu pendekatan ilmiah yang memandang suatu realitas dapat diklasifikasikan, konkrit, teramati dan terukur, hubungan variabelnya bersifat sebab akibat dimana data penelitiannya berupa angka-angka dan analisisnya menggunakan statistik (Suliyanto, 2011). Penelitian ini akan mengukur tingkat penerimaan penggunaan metode e-learning sebagai media pembelajaran pada mahasiswa jurusan Akuntansi dan Teknik Informatika.

\section{Tempat dan Waktu Penelitian}

Penelitian ini dilakukan di LP3I College Tasikmalaya jurusan Teknik Informatika dan Akuntansi. Pengumpulan data dilakukan dari tanggal 24-27 Juni 2019.

\section{Populasi Penelitian}

Purposive sampling digunakan untuk menentukan sampel sesuai dengan kriteria tertentu. Sample dalam penelitian ini adalah mahasiswa jurusan Akuntansi dan Teknik Informatika LP3I College Tasikmalaya angkatan 2018 yang sudah pernah menggunakan media pembelajaran berbasis e-learning dalam perkuliahan. Sample untuk mahasiswa Akuntansi sebanyak 30 orang dan mahasiswa Teknik Informatika sebanyak 30 orang.

\section{Teknik Pengumpulan Data}

Data dalam penelitian ini dikumpulkan melalui kuisioner menggunakan google form yang terdiri dari 30 pertanyaan yang diajukan kepada mahasiswa LP3I College Tasikmalaya jurusan Teknik Informatika dan Akuntansi. 


\section{Teknik Analisis Data}

Teknik analisis data dalam penelitian ini menggunakan analisis regresi. Analisis regresi dalam penelitian ini bertujuan untuk menguji hipotesis. Secara umum formula regresi yang digunakan dalam penelitian ini disajikan dalam persamaa (1).

$$
\begin{aligned}
& \mathrm{Y}=\alpha+\beta \mathrm{X}_{1}+\beta \mathrm{X}_{2}+\mathrm{e} \ldots \ldots \ldots \ldots \ldots \ldots \ldots \ldots \ldots \ldots \ldots \ldots \\
& \text { Keterangan: } \\
& \mathrm{Y} \quad=\text { Variabel dependen (Minat) } \\
& \mathrm{X}_{1}=\text { Variabel independen (Kegunaan) } \\
& \mathrm{X}_{2}=\text { Variabel independen (Kemudahan) } \\
& \alpha \quad=\text { Konstanta } \\
& \beta \quad=\text { Koefisien regresi } \\
& \mathrm{e} \quad=\text { error }
\end{aligned}
$$

\section{HASIL DAN PEMBAHASAN}

\section{Pembahasan}

Setelah melakukan berbagai pengujian asumsi klasik dan data dinyatakan layak maka data diolah dengan menggunakan regresi, sehingga diperoleh hasil.

1. Statistik Deskriptif

\section{a. Mahasiswa Jurusan Akuntansi}

Tabel 2. Statistik Deskriptif Variabel Kegunaan Mahasiswa Akuntansi

\begin{tabular}{|c|c|c|c|c|c|}
\hline & $\mathbf{N}$ & Mini mum & Maxi mum & Mean & Std. Deviation \\
\hline akt21 & 30 & 2.00 & 5.00 & 4.0667 & .63968 \\
\hline akt22 & 30 & 2.00 & 5.00 & 3.7333 & .86834 \\
\hline akt23 & 30 & 2.00 & 5.00 & 3.6667 & .80230 \\
\hline akt24 & 30 & 2.00 & 5.00 & 3.9667 & .61495 \\
\hline akt25 & 30 & 2.00 & 5.00 & 3.8667 & .62881 \\
\hline akt26 & 30 & 2.00 & 5.00 & 3.9000 & .71197 \\
\hline akt27 & 30 & 2.00 & 5.00 & 3.6333 & .76489 \\
\hline
\end{tabular}

\begin{tabular}{lrrrrr}
\hline & N & Mini mum & Maxi mum & Mean & Std. Deviation \\
\hline akt11 & 30 & 1.00 & 5.00 & 3.3448 & 1.14255 \\
\hline akt12 & 30 & 2.00 & 5.00 & 3.5333 & .89955 \\
\hline akt13 & 30 & 2.00 & 5.00 & 3.8000 & .80516 \\
\hline akt14 & 30 & 2.00 & 5.00 & 3.5000 & 1.00858 \\
\hline akt15 & 30 & 2.00 & 5.00 & 3.5000 & .86103 \\
\hline akt16 & 30 & 2.00 & 5.00 & 3.6333 & .88992 \\
\hline akt17 & 30 & 2.00 & 5.00 & 3.6667 & .92227 \\
\hline akt18 & 30 & 2.00 & 5.00 & 3.7333 & .82768 \\
\hline akt19 & 30 & 2.00 & 5.00 & 3.8000 & .96132 \\
\hline akt110 & 30 & 2.00 & 5.00 & 3.8333 & .79148 \\
\hline Valid N (listwise) & 30 & & & & \\
\hline
\end{tabular}

Berdasarkan data pada tabel 2, diketahui bahwa responden mahasiswa jurusan Akuntansi memilih jawaban minimum skala 1 (sangat setuju) untuk pernyataan pertama berkaitan dengan pengukuran persepsi kegunaan penggunaan e-learning, sementara jawaban untuk pernyataan ke 2 sampai dengan 10 berada pada skala 2 (setuju). Untuk respon maksimum jawaban responden berada pada skala 5 (sangat tidak setuju).

Tabel 3. Statistik Deskriptif Variabel Kemudahan Mahasiswa Akuntansi 
Jurnal Pendidikan Akuntansi Indonesia, Vol. 18, No. 1, Tahun 2020

Liana Dewi, Anisa Sains Kharisma \& Adib Noor Asy'ari

Hal. 1 - 11

\begin{tabular}{llllll}
\hline akt28 & 30 & 2.00 & 5.00 & 3.5000 & .73108 \\
\hline akt29 & 30 & 2.00 & 5.00 & 3.6333 & .80872 \\
\hline akt210 & 30 & 2.00 & 5.00 & 3.9333 & .73968 \\
\hline Valid N (listwise) & 30 & & & &
\end{tabular}

Berdasarkan data pada tabel 3, diketahui bahwa responden memilih jawaban minimum yang berkaitan dengan pengukuran persepsi kemudahan penggunaan e-learning pada skala 2 (setuju). Untuk respon maksimum jawaban responden pada skala 5 (sangat tidak setuju).

Tabel 4. Statistik Deskriptif Variabel Motivasi Penggunaan E-learning Mahasiswa Akuntansi

\begin{tabular}{llrrrr}
\hline & N & Mini mum & Maxi mum & Mean & Std. Deviation \\
\hline Yakt1 & 30 & 2.00 & 5.00 & 3.6000 & .81368 \\
\hline Yakt2 & 30 & 2.00 & 5.00 & 3.6000 & .96847 \\
\hline Yakt3 & 30 & 2.00 & 5.00 & 3.4000 & 1.03724 \\
\hline Yakt4 & 30 & 2.00 & 5.00 & 3.8000 & .55086 \\
\hline Yakt5 & 30 & 1.00 & 5.00 & 3.6000 & .89443 \\
\hline Yakt6 & 30 & 2.00 & 5.00 & 3.6667 & .71116 \\
\hline Yakt7 & 30 & 2.00 & 5.00 & 3.4667 & .89955 \\
\hline Yakt8 & 30 & 2.00 & 5.00 & 3.3667 & .88992 \\
\hline Yakt9 & 30 & 2.00 & 5.00 & 3.6333 & .71840 \\
\hline Yakt10 & 30 & 2.00 & 5.00 & 3.6333 & .71840 \\
\hline Valid N (listwise) & 30 & & & &
\end{tabular}

Berdasarkan data pada tabel 4, diketaui bahwa responden memilih jawaban minimum yang berkaitan dengan pengukuran motivasi penggunaan e-learning pada skala 2 (setuju). Untuk respon maksimum jawaban responden pada skala 5 (sangat tidak setuju).

\section{b. Mahasiswa Jurusan Teknik Informatika}

Tabel 5. Statistik Deskriptif Variabel Persepsi Kegunaan Mahasiswa Teknik Informatika

\begin{tabular}{|c|c|c|c|c|c|}
\hline & $\mathbf{N}$ & Mini mum & Maxi mum & Mean & Std. Deviation \\
\hline inf11 & 30 & 1.00 & 5.00 & 3.9667 & .85029 \\
\hline inf12 & 30 & 1.00 & 5.00 & 3.8000 & .96132 \\
\hline inf13 & 30 & 1.00 & 5.00 & 3.9667 & .88992 \\
\hline inf14 & 30 & 1.00 & 5.00 & 4.0333 & .96431 \\
\hline inf15 & 30 & 1.00 & 5.00 & 3.9000 & .92289 \\
\hline inf16 & 30 & 1.00 & 5.00 & 3.7000 & .79438 \\
\hline inf17 & 30 & 1.00 & 5.00 & 3.6333 & .80872 \\
\hline inf18 & 30 & 1.00 & 5.00 & 3.9000 & .88474 \\
\hline inf19 & 30 & 2.00 & 5.00 & 3.6667 & .80230 \\
\hline inf110 & 30 & 3.00 & 5.00 & 4.0667 & .63968 \\
\hline
\end{tabular}

Berdasarkan data pada tabel 5, diketahui bahwa responden mahasiswa Teknik Informatika memilih jawaban minimum skala 1 (sangat setuju) untuk pernyataan 1 sampai 8 berkaitan dengan pengukuran persepsi kegunaan penggunaan e-learning sementara jawaban untuk 
pernyataan 9 pada skala 2 (setuju) dan 3 (ragu-ragu) untuk pernyataan 10. Untuk respon maksimum jawaban responden pada skala 5 (sangat tidak setuju) padasetiap pernyataan.

Tabel 6. Statistik Deskriptif Variabel Kemudahan Mahasiswa Teknik Informatika

\begin{tabular}{lcrrrr}
\hline & N & Mini mum & Maxi mum & \multicolumn{1}{c}{ Mean } & Std. Deviation \\
\hline inf21 & 30 & 3.00 & 5.00 & 4.1000 & .71197 \\
\hline inf22 & 30 & 2.00 & 5.00 & 3.8333 & .83391 \\
\hline inf23 & 30 & 2.00 & 5.00 & 3.6000 & .72397 \\
\hline inf24 & 30 & 3.00 & 5.00 & 4.0000 & .58722 \\
\hline inf25 & 30 & 2.00 & 5.00 & 3.8333 & .69893 \\
\hline inf26 & 30 & 2.00 & 5.00 & 3.6667 & .75810 \\
\hline inf27 & 30 & 2.00 & 5.00 & 3.5667 & .72793 \\
\hline inf28 & 30 & 2.00 & 5.00 & 3.4333 & .77385 \\
\hline inf29 & 30 & 1.00 & 5.00 & 3.5333 & .97320 \\
\hline inf210 & 30 & 1.00 & 5.00 & 3.7333 & .90719 \\
\hline Valid N (listwise) & 30 & & & &
\end{tabular}

Berdasarkan data pada tabel 6, diketahui bahwa responden memilih jawaban minimum skala 1 (sangat setuju) untuk pernyataan 9 dan 10 berkaitan dengan pengukuran persepsi kemudahan penggunaan $e$-learning, skala 2 (setuju) untuk pernyataan $2 ; 3 ; 5 ; 6 ; 7 ; 8$, dan skala 3 (ragu-ragu) untuk pernyataan 1 serta 4 . Untuk respon maksimum jawaban responden pada skala 5 (sangat tidak setuju) pada setiap pernyataan.

Tabel 7. Statistik Deskriptif Variabel Motivasi Penggunaan E-learning

\begin{tabular}{llrrrr}
\hline & N & Mini mum & Maxi mum & Mean & Std. Deviation \\
\hline Yinf1 & 30 & 2.00 & 5.00 & 3.5667 & .77385 \\
\hline Yinf2 & 30 & 2.00 & 5.00 & 3.5667 & .67891 \\
\hline Yinf3 & 30 & 2.00 & 5.00 & 3.3667 & .76489 \\
\hline Yinf4 & 30 & 3.00 & 5.00 & 3.8000 & .66436 \\
\hline Yinf5 & 30 & 2.00 & 5.00 & 3.1000 & 1.02889 \\
\hline Yinf6 & 30 & 2.00 & 5.00 & 3.9333 & .63968 \\
\hline Yinf7 & 30 & 2.00 & 5.00 & 3.8667 & .68145 \\
\hline Yinf8 & 30 & 2.00 & 5.00 & 3.7333 & .63968 \\
\hline Yinf9 & 30 & 1.00 & 5.00 & 3.6000 & .81368 \\
\hline Yinf10 & 30 & 3.00 & 5.00 & 3.8667 & .62881 \\
\hline Valid N (listwise) & 29 & & & &
\end{tabular}

Berdasarkan tabel 7, responden memilih jawaban minimum skala 1 (sangat setuju) untuk pernyataan 9 berkaitan dengan pengukuran motivasi penggunaan $e$-learning, skala 2 (setuju) untuk pernyataan $1 ; 2 ; 3 ; 5 ; 6 ; 7 ; 8$, dan skala 3 (ragu-ragu) untuk pernyataan 4 serta 10 . Untuk respon maksimum jawaban responden pada skala 5 (sangat tidak setuju) pada setiap pernyataan.

Dari data statistik tersebut dapat diketahui bahwa jawaban responden untuk mahasiswa jurusan Akuntansi lebih seragam dibandingkan dengan jawaban responden mahasiswa Teknik Informatika untuk jawaban minimumnya, sementara untuk jawaban maksimum mahasiswa Akuntansi maupun mahasiswa Teknik Informatika memiliki jawaban seragam pada skala 5 
(sangat tidak setuju). Untuk rata-rata respon dari mahasiswa kedua jurusan tersebut berasa diatas skala 3 .

\section{Pengujian X1 dan X2 terhadap Y untuk mahasiswa jurusan Akuntansi}

Tabel 8. Hasil Uji F jurusan Akuntansi

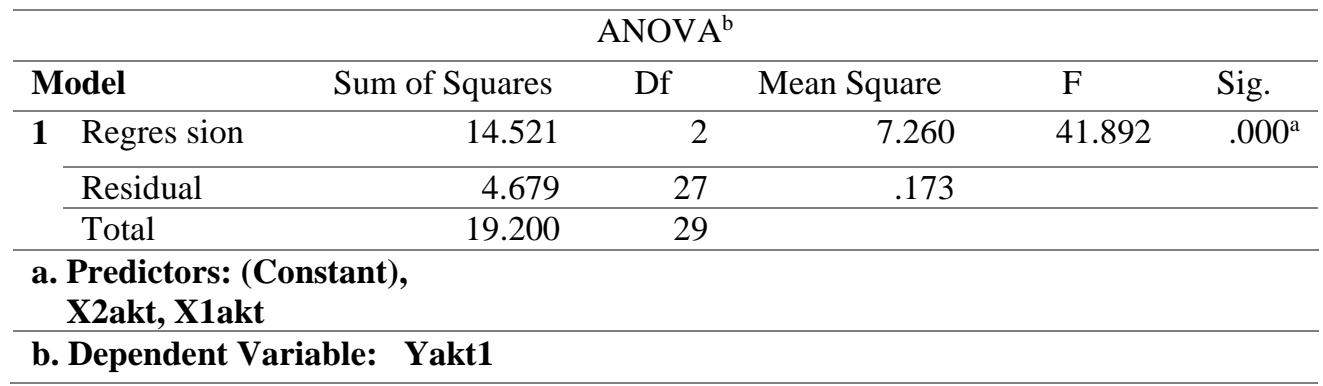

Hasil pengujian X1 dan X2 terhadap Y Akuntansi ini memiliki arah yang positif serta signifikan karena tingkat signifikansi dalam tabel 2 menunjukkan angka dibawah $0,05(0,000$ $\leq 0,05)$. Hal ini menjelaskan bahwa model regresi untuk penelitian yang digunakan telah sesuai.

Tabel 9. Hasil Uji t jurusan Akuntansi

\begin{tabular}{|c|c|c|c|c|c|c|}
\hline \multicolumn{7}{|c|}{ Coefficients $^{\mathrm{a}}$} \\
\hline \multirow{2}{*}{\multicolumn{2}{|c|}{ Model }} & \multicolumn{2}{|c|}{$\begin{array}{l}\text { Unstandardized } \\
\text { Coefficients }\end{array}$} & \multirow{2}{*}{$\begin{array}{c}\text { Standar dized } \\
\text { Coeffi cients } \\
\text { Beta }\end{array}$} & \multirow[t]{2}{*}{$\mathrm{t}$} & \multirow[t]{2}{*}{ Sig. } \\
\hline & & B & Std. Error & & & \\
\hline \multirow[t]{4}{*}{1} & (Constant) & - & .652 & & -.807 & .427 \\
\hline & & .526 & & & & \\
\hline & X1akt & .059 & .024 & .551 & 2.439 & .022 \\
\hline & X2akt & .052 & .035 & .338 & 1.498 & .146 \\
\hline
\end{tabular}

a. Dependent Variable: Yakt1

Dari tabel 9 dapat dilihat bahwa X1 Akuntansi berpengaruh postif signifikan terhadap Y dengan signifikansi dibawah $0,05(0,022 \leq 0,05)$ sedangkan X2 Akuntansi berpengaruh positif saja terhadap Y $(0,146 \geq 0,05)$. Hasil pengujian X1 maupun X2 terhadap Y mendukung hipotesis ke 1a dan 2a yang menyatakan bahwa X1 dan X2 Akuntansi secara parsial berpengaruh positif terhadap Y Akuntansi. Namun ternyata persepsi kegunaan lebih berpengaruh terhadap motivasi penggunaan e-learning pada mahasiswa jurusan Akuntansi dibandingkan dengan persepsi kemudahan dalam penggunaannya.

\section{Pengujian X1 dan X2 terhadap Y untuk mahasiswa jurusan Teknik Informatika}

Tabel 10. Hasil Uji F jurusan Teknik Informatika

\begin{tabular}{|c|c|c|c|c|c|}
\hline \multicolumn{6}{|c|}{$\mathrm{ANOVA}^{\mathrm{b}}$} \\
\hline Model & Sum of Squares & Df & Mean Square & $\mathrm{F}$ & Sig. \\
\hline 1 Regres sion & 658.264 & 2 & 329.132 & $\begin{array}{r}53.2 \\
33\end{array}$ & $.000^{\mathrm{a}}$ \\
\hline Residual & 166.936 & 27 & 6.183 & & \\
\hline Total & 825.200 & 29 & & & \\
\hline a. Predictors: ( & stant), X2inf, X1in & & & & \\
\hline b. Dependent V & le: Yinf & & & & \\
\hline
\end{tabular}


Hasil uji f pada Jurusan Teknik Informatika juga bernilai positif dan signifikan karena nilai signifikansinya dibawah $0,05(0,000 \leq 0,05)$ yang artinya model regresi yang digunakan telah sesuai (goodness of fit). Selanjutnya dapat dilakukan pengujian dengan menggunakan uji t untuk mengetahui pengaruh persepsi kegunaan dan kemudahan terhadap minat penggunaan $e$ learning bagi mahasiswa Teknik Informatika.

Tabel 11. Hasil Uji t jurusan Teknik

Teknik Informatika

\begin{tabular}{|c|c|c|c|c|c|}
\hline \multicolumn{6}{|c|}{ Coefficients $^{\mathrm{a}}$} \\
\hline \multirow[t]{2}{*}{ Model } & \multicolumn{2}{|c|}{$\begin{array}{l}\text { Unstandardized } \\
\text { Coefficients }\end{array}$} & \multirow{2}{*}{$\begin{array}{c}\text { Standar dized } \\
\text { Coeffi cients } \\
\text { Beta } \\
\end{array}$} & \multirow[t]{2}{*}{$\mathrm{t}$} & \multirow[t]{2}{*}{ Sig. } \\
\hline & $\mathrm{B}$ & Std. Error & & & \\
\hline 1 (Constant) & 3.802 & 3.269 & & 1.163 & .255 \\
\hline X1inf & .100 & .117 & .137 & .857 & .399 \\
\hline X2inf & .770 & .158 & .775 & 4.866 & .000 \\
\hline
\end{tabular}

a. Dependent Variable: Yinf

Dari tabel 11 dapat dilihat bahwa X1 dan X2 Teknik Informatika memiliki koefisien yang positif sehingga keduanya memiliki pengaruh yang positif terhadap Y. Untuk X1 Teknik Informatika dinyatakan hanya memiliki pengaruh yang positif terhadap Y namun sifatnya tidak signifikan karena tingkat signifikansinya lebih besar dari $0,05(0,399 \geq 0,05)$. X2 Teknik Informatika memiliki hubungan yang positif dan signifikan terhadap Y Teknik Informatika karena tingkat signifikansinya dibawah $0,05(0,000 \leq 0,05)$. Secara keseluruhan hipotesis $1 \mathrm{~b}$ dan $2 \mathrm{~b}$ didukung, X1 dan X2 Teknik Informatika berpengaruh positif terhadap Y. Jika dilihat secara rinci persepsi kemudahan lebih berpengaruh pada motivasi penggunaan e-learning pada mahasiswa jurusan Teknik Informatika dibandingkan dengan persepsi kegunaannya.

Berdasarkan hasil pengujian yang telah dijelaskan sebelumnya, dapat diketahui bahwa baik pada jurusan Akuntansi maupun jurusan Teknik Informatika, mahasiswa memiliki motivasi yang baik dalam menggunakan e-learning sebagai media pembelajaran. Pada mahasiswa jurusan Akuntansi persepsi kegunaan lebih mendominasi motivasi mahasiswa dalam penggunaan e-learning, sedangkan pada mahasiswa jurusan Teknik Informatika persepsi kemudahan mendominasi motivasi penggunaan e-learning.

Ini sesuai dengan penelitian sebelumnya, yang mengungkapkan bahwa mahasiswa pada bidang keilmuan sosial cenderung menyukai pembelajaran paper based, dibandingkan dengan mahasiswa sains dan teknik yang lebih suka web based (El-Seoud, Taj-Eddin, Seddiek, ElKhouly, \& Nosseir, 2014).

\section{SIMPULAN DAN SARAN}

\section{Simpulan}

Berdasarkan hasil pengujian statistik regresi dapat disimpulkan bahwa mahasiswa jurusan Akuntansi maupun Teknik Informatika memiliki motivasi yang baik terhadap penggunaan $e$ learning sebagai media pembelajaran.

Perbedaan terdapat pada persepsi yang mendominasi dari masing-masing jurusan. Mahasiswa Akuntansi lebih berfokus pada persepsi kegunaan dalam menggunakan $e$-learning, sedangkan mahasiswa Teknik Informatika lebih berfokus pada persepsi kemudahan. 


\section{Saran}

Penelitian dengan metode kualitatif maupun kuantitatif dengan sampel mahasiswa yang lebih banyak dan berasal dari berbagai bidang keilmuan atau program studi, serta sampel selain mahasiswa misalnya dosen merupakan tantangan yang dapat dicoba pada penelitian selanjutnya untuk mengetahui penyebab lain dari kurang optimalnya penggunaan $e$-learning sebagai media pembelajaran.

\section{DAFTAR PUSTAKA}

Asrori, A., \& Fachrurrozie, F. (2011). PENGGUNAAN E-LEARNING ILMO UNTUK MENINGKATKAN MUTU PERKULIAHAN DI FAKULTAS EKONOMI. JURNAL PENDIDIKAN EKONOMI DINAMIKA PENDIDIKAN, Vol. VI No. 1, 1- 14 .

Binus University. (2016, Desember 13). https://sis.binus.ac.id. Dipetik Juli 15, 2019, dari www.binus.ac.id: https://sis.binus.ac.id

Briosandhi, S. (2011). STUDI PENGGUNAAN E-LEARNING PROGDI AKUNTANSI UNIVERSITAS PEMBANGUNAN NASIONAL "VETERAN" JAWA TIMUR. Surabaya: UNIVERSITAS PEMBANGUNAN NASIONAL "VETERAN".

Caldarelli, A., Ferri, L., Maffei, M., \& Spanò, R. (2019). Accountants Are from Mars, ICT Practitioners Are from Venus.Predicting Technology Acceptance Between Two Groups. Organizing for Digital Innovation.

Davis, F. D., Bagozzi , R. P., \& Warshaw , P. R. (1989). User Acceptance of Computer Technology: A Comparison of Two Theoretical Models. Management Science, 982-1003.

El-Seoud , M. S., Taj-Eddin, I. A., Seddiek, N., El-Khouly, M. M., \& Nosseir, A. (2014). E-Learning and Students' Motivation: A Research Study on the Effect of E-Learning on Higher Education. International Journal of Emerging Technologies in Learning, 20-26.

Felix, F., \& Wirawan, A. R. (2014). EVALUASI PENERAPAN E-LEARNING DI JURUSAN AKUNTANSI FAKULTAS BISNIS DAN EKONOMIKA UNIVERSITAS SURABAYA. Jurnal Ilmiah Mahasiswa Universitas Surabaya, Vol.3 No.1.

Harahap, S. H. (2015). PEMANFAATAN E-LEARNING BERBASIS LCMS MOODLE SEBAGAI MEDIA PEMBELAJARAN UNTUK MATA KULIAH SISTEM INFORMASI AKUNTANSI. JURNAL RISET AKUNTANSI DAN BISNIS, Volume 15 No.1.

Hartanto, W. (2016). Penggunaan E-Learning Sebagai Media Pembelajaran. JURNAL PENDIDIKAN EKONOMI: Jurnal Ilmiah Ilmu Pendidikan, Ilmu Ekonomi dan Ilmu Sosial, Vol. 10, no. 1.

Sefrika, S. (2018). ANALISA PENERIMAAN TEKNOLOGI E-LEARNING PADA AMIK BSI. Journal Of Informatic Pelita Nusantara, Volume 3 No 1.

Simanjuntak, O. S. (2011). PENGEMBANGAN TECHNOLOGY ACCEPTANCE MODEL (TAM)SEBAGAI UPAYA PEMBERDAYAAN MASYARAKAT MENUJU MASYARAKAT INFORMASI. TELEMATIKA, 25 - 32.

Suliyanto. (2011). Ekonometrika Terapan: Teori dan Aplikasi dengan SPSS. Yogyakarta: Andi.

Yudi, S. E., \& Tambotoh, J. J. (2013). Analisis Pemanfaatan Teknologi Informasi Menggunakan Pendekatan Innovation dan Diffusion Theory (IDT) dan Technology Acceptance Model (TAM) pada Disdikpora Kota Salatiga. Salatiga: Universitas Kristen Satya Wacana.

Yulianto, S. E. (2011). PENGARUH PERSEPSI KEMUDAHAN DAN PERSEPSI KEMANFAATAN TERHADAP PEMANFAATAN E-LEARNING DENGAN MODEL TAM DI SMK MUHAMMADIYAH 3 YOGYAKARTA. JBTI, Vol.II, No.1. 